\title{
Detection of Helicobacter pylori in oral yeasts from students of a Chilean university
}

\author{
(D) Kimberly Sánchez-Alonzo' \\ (iD) Cristian Parra-Sepúlveda ${ }^{1}$ \\ (iD) Lorena Vergara ${ }^{2}$ \\ (iD) Humberto Bernasconi ${ }^{3}$ \\ (D) Apolinaria García-Cancino ${ }^{1}$
}

1. Laboratorio de Patogenicidad Bacteriana, Departamento de Microbiología, Facultad de Ciencias Biológicas, región del Biobío, Chile. 2. Departamento de Odontología Restauradora, Facultad de Odontología. Universidad de Concepción, Concepción, Chile. 3. Laboratorios Pasteur. Concepción, Chile.

http://dx.doi.org/10.1590/1806-9282.66.11.1509

\section{SUMMARY}

INTRODUCTION: Nearly 73\% of the Chilean population is infected with Helicobacter pylori (H. pylori), a factor predisposing for gastric cancer. Recent studies have demonstrated the presence of this pathogen within yeasts, suggesting that this fact can directly influence the failure of a treatment, transmission, and reinfection.

AIM: To detect the presence of H. pylori inside oral yeasts isolated from students of the University of Concepción (Chile).

METHODS: 72 samples, obtained from the oral cavity using cotton swabs were incubated in YPD broth for $48 \mathrm{~h}$ at $37^{\circ} \mathrm{C}$ and posteriorly seeded in Sabouraud Dextrose agar plus chloramphenicol at the same temperature and for the same time. Yeasts isolated were observed microscopically (wet mounting and Gram-stained) and identified using microbiological techniques. Intracellular H. pylori detection was performed by the amplification of $16 \mathrm{~S}$ rDNA by PCR.

RESULTS: Oral yeasts were detected in 24 samples (33.3\%), being C. albicans (79.2\%) the most frequent species, followed by C. dubliniensis (12.4\%), C. krusei (4.2\%), and C. tropicalis (4.2\%). When analyzed by PCR, 15 of the 24 oral yeasts $62.5 \%$ were positive for $\mathrm{H}$. pylori $16 \mathrm{~S}$ rDNA. From the 15 individuals positive for yeast harboring H. pylori, 81\% of them reported stomach discomfort, and the presence of the bacteria was diagnosed at some moment in $20 \%$ of them.

CONCLUSION: The intracellular presence of the H. pylori in oral yeasts suggests an endosymbiotic relationship of these microorganisms, which could favor $\mathrm{H}$. pylori transmission and reinfection in the gastrointestinal tract.

KEYWORDS: Helicobacter pylori. Candida. Mouth.

\section{INTRODUCTION}

H. pylori is a Gram-negative bacterium with several virulence factors, which allow it to selectively colonize the gastric mucosa. It is the etiological agent of several gastrointestinal diseases in humans ${ }^{1-3}$. The latter acts as its main reservoir, acquiring an infection mainly during childhood, supposedly in the intrafamily environment. However, how this pathogen spreads is not fully understood; up until now, it is accepted that its transmission occurs through the oral-oral and fecaloral route. Although H. pylori has been studied for decades, questions remain regarding how it spreads among populations, since $H$. pylori genes have been

DATE OF SUBMISSION: 30-May-2020

DATE OF ACCEPTANCE: $17-$ Jul-2020

CORRESPONDING AUTHOR: Apolinaria García-Cancino

Departamento de Microbiología, Universidad de Concepción, Concepción, Región del Biobío, Chile

Tel: +56 41220-4144 / Fax: +56 41 224-5975

E-mail: apgarcia@udec.cl 
amplified in different sources, including food and water, with no success in the isolation of this bacterium through cultivation ${ }^{2,4,5}$. H. pylori infects more than $50 \%$ of the world population and is considered the main predisposing factor to the development of gastric cancer ${ }^{6}$. In Chile, its prevalence is $73 \%$ in children older than 17 years and is significantly higher in individuals of lower socioeconomic classes and males?

H. pylori infections are a public health problem worldwide, and it features in the list of pathogens with high priority by $\mathrm{WHO}^{8}$, which makes us ask: What makes H. pylori such an effective pathogen? One way to answer this question is by saying that this pathogen has multiple virulence factors, which ensure its effective colonization. In addition, it is a facultative intracellular microorganism able to invade and multiply itself inside vacuoles of eukaryotic cells, including yeasts of the genus Candida ${ }^{2,9,10}$.

There is evidence that H. pylori and Candida share habits in areas of the human anatomy, such as in the mouth, which is the anatomical site for the entry of microorganisms that colonize the digestive apparatus, in addition to the fact that both microorganisms can survive in the acidic environment of the stom$\operatorname{ach}^{11-13}$, which would favor their interaction and the internalization of the bacterium in the yeast, which would grant it protection, nutrition, and a transmission medium that would allow the bacteria to survive outside the human gastrointestinal environment since yeast can survive in different environments, including in conditions with a lack of nutrients ${ }^{2.1014}$.16.

The high prevalence of gastrointestinal diseases associated with $\mathrm{H}$. pylori, the increased resistance of this pathogen to antibiotic treatment ${ }^{17.18}$, and the lack of knowledge regarding its means of transmission make it necessary to obtain evidence that allows developing effective strategies to reduce its spread and, consequently, the prevalence of pathologies associated to its infection. For this reason, the goal of this study was to detect the presence of $\mathrm{H}$. pylori in intracellular yeasts of the genus Candida of oral origin isolated from young graduates of the University of Concepción, Chile.

\section{METHODS}

This study was approved by the ethics committee of the University of Concepción, under number E-224-18. Prior to the sample collection, each participant received information, oral and written, about the importance of the study and how the sample would be collected. In addition, we explained they could leave the study at any stage. We carried out a quantitative, observational, transversal study. Our population consisted of undergraduate students of the University of Concepción.

\section{Inclusion criteria}

Signing the informed consent form.

\section{Exclusion criteria}

Treatment with antifungal agents a month before or at the time of sample collection.

\section{Questionnaire}

The people who participated in the study individually filled out a questionnaire with the questions: 1) Have you presented or do you present stomach discomfort in the last 30 days? 2) What kind of discomfort is/was that? (Gastritis/Reflux/Abdominal pain/ Nausea/Vomiting/Diarrhea), 3) What was the duration of the discomfort? (Hours/A day/ More than a day/ More than a week), 4) Do you wash your hands before and after using the restroom?, 5) Do you drink potable water, bottled water, or non-potable water?, 6) Were you diagnosed with any gastrointestinal pathology? 7) Have you ever been diagnosed with H. pylori?, 8) Has any of your relatives ever been diagnosed $H$. pylori?

\section{Sample collection}

Participants were instructed not to brush their teeth for at least two hours before the sample collection. The sample was collected orally with a cotton swab, which was scraped on the cheeks, soft palate, tongue's surface, underneath the tongue, and gums, according to Matamala-Valdés et al. ${ }^{2}$. Subsequently, each swab was placed in test tubes with $5 \mathrm{~mL}$ of liquid YPD (Difco, USA), which were incubated in aerobic conditions for 48 hours. After that, each sample was seeded on Sabouraud Dextrose Agar plates (Difco, USA) supplemented with Chloramphenicol (Oxoid, United Kingdom) rubbing the swab across the entire surface of the culture medium; the plates were incubated at $37^{\circ} \mathrm{C}$ for 48 hours under aerobic conditions. Subsequently, we confirmed the growth of pure yeasts through wet Gram staining. From the primary culture, two consecutive seedings were carried out in Sabouraud Dextrose Agar (Difco, USA), supplemented with Chloramphenicol (Oxoid, United Kingdom) to ensure the purity of the sample; each re-seeding was followed by wet Gram staining examination. 
Detection of bacterium-like organelles (BLOs) on the inside of fungal cells by optical microscopy.

We carried out a wet examination in yeast colonies randomly chosen in search of BLOs inside the fungal cells, using as a negative control C. albicans ATCC 90028. Each colony was placed in $20 \mu \mathrm{L}$ of saline solution and observed using an optical microscope, with a 100X objective lens.

\section{Tests for the identification of Candida spp.}

We took an inoculum from the crops of pure yeast in Sabouraud Agar, which was then sown on CHROMagar Candida (Difco, USA) and incubated under aerobic conditions at $37^{\circ} \mathrm{C}$ for $24-48$ hours. The interpretation was performed according to the manufacturer's instructions. Subsequently, the results were confirmed using the identification system API ${ }^{\circledR} \mathrm{Can}$ dida, following the manufacturer's recommendations (BIOMÉRIEUX, France).

\section{DNA extraction}

The total DNA from the yeast isolated from the oral swab samples and controls was extracted from pure cultures obtained in Sabouraud Agar, using the commercial kit UltraClean ${ }^{\circledR}$ Microbial DNA Isolation (MO BIO lab) and following the manufacturer's instructions. The quantification and degree of purity of the DNA extracted was obtained by spectrophotometry (TECAN, Switzerland)

\section{Genotyping of Helicobacter pylori}

The amplification of the $16 \mathrm{~S}$ rDNA of the $\mathrm{H}$. pylori and the electrophoresis of the amplified products was carried out according to the protocol described by Matamala-Valdés et al. ${ }^{2}$.

\section{Statistical analysis}

The data obtained in this study were processed using the XLSTAT software 2017. We used Fisher's exact test to determine the relationship between the categorical variables. The level of significance used was 0.05 , considering a value significant whenever $\mathrm{p}<0.05$.

\section{RESULTS}

Prevalence of oral yeasts

A total of 72 students participated in the study, 30 of whom were women and 42 men. Of the 72 oral swab samples, there was a prevalence of $33.3 \%(24 / 72)$ of oral yeasts. The yeast species isolated with greater frequency in the oral mucosa was C. albicans with $79.2 \%$, followed by C. dubliniensis with $12.4 \%$, C. krusei with $4.2 \%$, and C. tropicalis with $4.2 \%$.

\section{Observation by optical microscopy}

The observation of the samples by optical microscopy revealed the presence of BLOs in 15/24 (63\%) of the isolated yeast samples; the BLOs were observed quickly and continuously detaching themselves inside the yeast vacuoles (Figure 1).

\section{FIGURE 1}

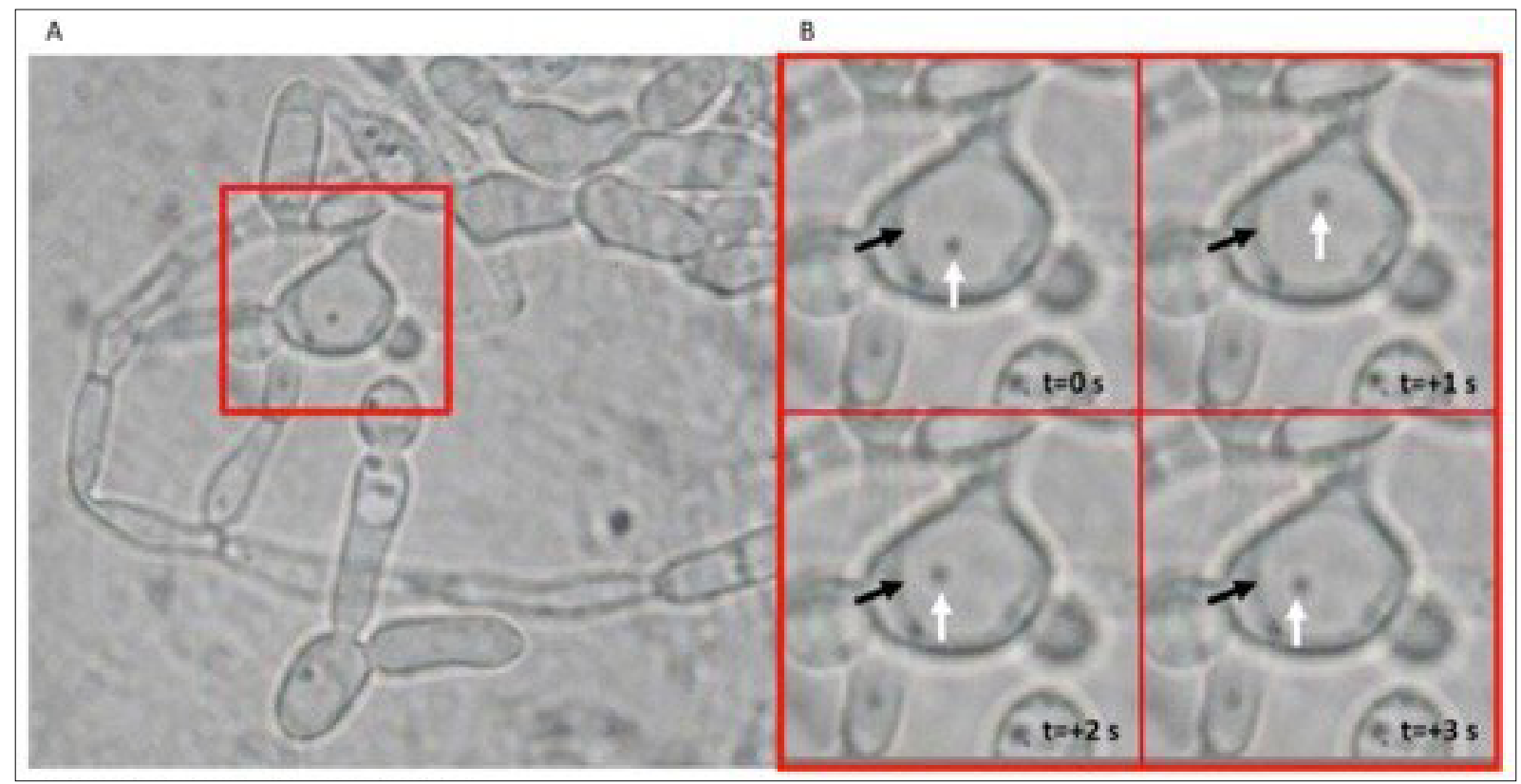

Kimberly Sánchez-Alonzo 


\section{Amplification of the 16S rDNA gene}

We amplified the $16 S$ rDNA gene of the H. pylori in $63 \%$ of the oral yeasts $(15 / 24)$, which was in line with the 15 samples of yeast in which the BLOs were observed (Figure 2).

\section{Results of the applied research}

Regarding the results obtained from the questionnaire with the 72 participants, we found that $80 \%$ of the 15 participants from whom oral yeasts with $H$. pylori were isolated had had some stomach discomfort in the thirty days prior to the sample collection, and the most frequent type of discomfort was abdominal pain and gastritis, with $33 \%$ and $27 \%$, respectively (Table 1). In addition, out of the 15 participants with oral yeasts positive for $\mathrm{H}$. pylori, $20 \%$ had been diagnosed at some time with $H$. pylori, and $33.3 \%$ had a relative with a diagnosis of $H$. pylori infection at some time in their lives (Tables 2 and 3).

Association of intracellular $H$. pylori in yeasts and information obtained from the research.

Fisher's exact test showed that there was no statistically significant association between the presence of stomach discomfort and the amplification of the $16 \mathrm{~S}$ rDNA gene of the $H$. pylori in the DNA extracted from the oral yeasts $(p=0.569)$. No statistically significant association was observed between the positive diagnosis for H. pylori, and the amplification of the 16S rDNA gene for the H. pylori, also based on the total DNA from oral yeasts $(p=0.154)$. Finally, when applying

\section{FIGURE 2}

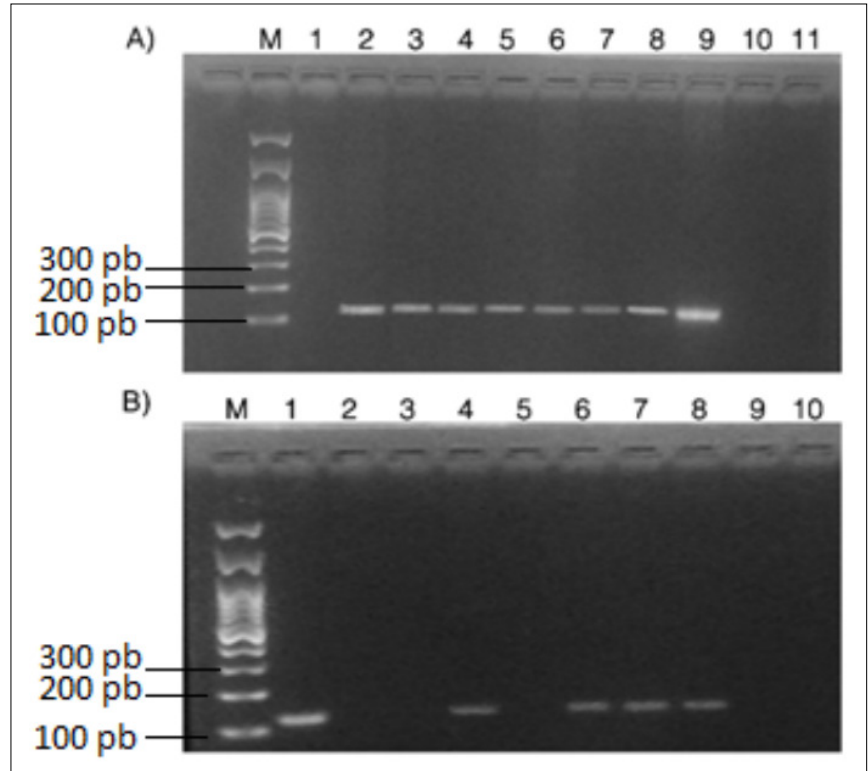

Kimberly Sánchez-Alonzo
Fisher's exact test for the association of the diagnosis of a patient's family member with $\mathrm{H}$. pylori and the amplification of the 16S rDNA gene for H. pylori, we obtained a p-value of 1.0, indicating that there was no statistical significance for this association.

\section{DISCUSSION}

The coexistence of H. pylori and Candida spp. has existed for a long time; however, the benefits the bacteria receive when entering the yeast remain unknown ${ }^{2,10,14,19}$. Furthermore, cases have been reported of bacteria that enter fungi to protect themselves from environmental stress. An example of that is the endosymbiotic relationship between

TABLE 1. PERCENTAGE OF STOMACH DISCOMFORT REPORTED BY STUDY PARTICIPANTS, FROM WHOM ORAL YEASTS WITH INTRACELLULAR H.PYLORI WERE ISOLATED.

\begin{tabular}{l|l|l} 
Type of discomfort & Frequency & Percentage \\
\hline Abdominal pain & 5 & $33 \%$ \\
\hline Gastritis & 4 & $27 \%$ \\
\hline Reflux & 1 & $7 \%$ \\
\hline Vomiting & 0 & $0 \%$ \\
\hline Nausea & 1 & $7 \%$ \\
\hline Diarrhea & 1 & $7 \%$ \\
\hline Did not report discomfort & 3 & $19 \%$ \\
\hline Total & 15 & $100 \%$ \\
\hline
\end{tabular}

TABLE 2. RELATIONSHIP BETWEEN PARTICIPANTS DIAGNOSED WITH INFECTION BY H. PYLORI AND THE MOLECULAR IDENTIFICATION OF THIS PATHOGEN IN YEASTS FROM THE ORAL CAVITY.

\begin{tabular}{l|l|l|l} 
Diagnosis & $\begin{array}{l}\text { Samples with ampli- } \\
\text { fied 16S rDNA of the } \\
\text { H. Pylori }\end{array}$ & $\begin{array}{l}\text { Samples without } \\
\text { amplified 16S rDNA } \\
\text { of the H. Pylori }\end{array}$ & Total \\
\hline Yes & 1 & 2 & 3 \\
\hline No & 10 & 2 & 12 \\
\hline Total & 11 & 4 & 15 \\
\hline
\end{tabular}

TABLE 3. RELATIONSHIP BETWEEN PARTICIPANTS' FAMILY MEMBERS DIAGNOSED WITH AN INFECTION BY H. PYLORI AND THE MOLECULAR IDENTIFICATION OF THIS PATHOGEN IN YEASTS FROM THE ORAL CAVITY.

\begin{tabular}{l|l|l|l} 
Diagnosis & $\begin{array}{l}\text { Samples with ampli- } \\
\text { fied 16S rDNA of the } \\
\text { H. pylori }\end{array}$ & $\begin{array}{l}\text { Samples without } \\
\text { amplified 16S rDNA } \\
\text { of the H. pylori }\end{array}$ & Total \\
\hline Yes & 4 & 1 & 5 \\
\hline No & 7 & 3 & 10 \\
\hline Total & 11 & 4 & 15 \\
\hline
\end{tabular}


the Candidatus glomeribacter and the Micorriza arbuscular ${ }^{20,21}$.

The yeasts of the Candida genus are part of the human microbiota and are distributed in greater volume in the oral cavity on the tongue's surface, the palate and in the oral mucosa ${ }^{22}{ }^{23}$; on the other hand, the presence of $H$. pylori in the oral cavity was detected by molecular tests $2,10,14,19,24$. However, there are scarce cases of these bacteria being isolated on this anatomical site, assuming that DNA fragments of $H$. pylori can become lodged in the mouth through the reflux in patients infected at the gastric level ${ }^{25}$ or that it is temporarily lodged in the mouth, indicating that the oral microenvironment does not provide the conditions necessary for the survival of the bacteria, which would force $H$. pylori to create strategies to protect itself from unfavorable environments, such as entering oral yeasts, a phenomenon demonstrated by research conducted by Siavoshi et al. ${ }^{10} .{ }^{14}$ and Matamala-Valdés et al. .

In the general population, the percentage of people with oral Candida spp. varies between $17-75 \%{ }^{17} \cdot{ }^{24}$, and $75 \%$ of the isolates from the oral mucosa correspond to C. albicans, followed by C. tropicalis (8\%), and C. krusei $(3-6 \%)^{23}$. In the present study, the isolated species in order of frequency were C. albicans with $79.2 \%$, followed by C. dubliniensis with $12.5 \%$, C. krusei (4.2\%), and $C$. tropicalis with $4.2 \%$, in agreement with the data presented by the bibliography reviewed.

Regarding the observation by optical microscopy of the wet examination of the oral yeasts with H. pylori, we found that the bacteria movement was limited to the size of the vacuole; in addition, the presence of intravacuolar $H$. pylori was observed both in yeast obtained from primary culture and on re-seedings, which suggests that this microorganism is not only capable of entering the yeast, but also possibly of reproducing inside the fungal cell. This same essay allowed us to observe that there was an increase in the size of the yeast vacuoles with $H$. pylori when compared to those without the presence of the bacteria; (Figure 1).

\section{Acknowledgments}

We thank all the students who collaborated in the study by donating their oral samples.

\section{Funding}

Resources from the VRID-Asociativos Project 218.102.028-1.0, University of Concepción.

\section{Ethical aspects}

The authors of this study declare there are no conflicts of interest. This research was approved by the Scientific Ethics Committee of the Faculty of Biological Sciences of the University of Concepción, Concepcion - Chile, under number E-224-18 and was approved on 7 March 2018.

\section{Author's Contribution}

Collection: Kimberly Sánchez-Alonzo, Cristian Parra-Sepúlveda, Lorena Vergara. Processing of samples: Kimberly Sánchez- Alonzo, Cristian Parra-Sepúlveda, Humberto Bernasconi. Analysis of results and writing of the scientific paper: Kimberly Sánchez- Alonzo, Cristian Parra-Sepúlveda, Apolinaria García-Cancino. Management for funding: Lorena Vergara, Apolinaria García-Cancino.

\section{RESUMO}

INTRODUÇão: Quase 73\% da população chilena estão infectadas pelo Helicobacter pylori (H. pylori), fator predisponente ao câncer gástrico. Estudos recentes demonstraram a presença desse patógeno em leveduras, sugerindo que esse fato pode influenciar diretamente a falha de um tratamento, transmissão e reinfecção.

OBJETIVO: Detectar a presença de H. pylori em leveduras orais isoladas de estudantes da Universidade de Concepción (Chile).

MÉTODOS: 72 amostras, obtidas da cavidade oral utilizando cotonetes, foram incubadas em caldo YPD por $48 \mathrm{~h}$ a $37^{\circ} \mathrm{C}$ e posteriormente sementes em ágar Sabouraud Dextrose mais cloranfenicol na mesma temperatura e ao mesmo tempo. Leveduras isoladas foram observadas microscopicamente (montagem úmida e corada por Gram) e identificadas utilizando técnicas microbiológicas. A detecção intracelular de H. pylori foi realizada pela amplificação do $16 \mathrm{~S}$ rDNA por PCR.

RESULTADOS: Leveduras orais foram detectadas em 24 amostras (33,3\%), sendo C. albicans (79,2\%), a espécie mais frequente seguida por C. dubliniensis (12,4\%), C. krusei (4,2\%) e C. tropicalis (4,2\%) Quando analisadas por PCR, 15 das 24 leveduras orais 62,5\% foram positivas para o H. pylori $16 \mathrm{~S}$ rDNA. Dos 15 indivíduos positivos para leveduras que abrigam H. pylori, $81 \%$ deles relataram desconforto estomacal e a presença da bactéria foi diagnosticada em algum momento em $20 \%$ deles.

CONCLUSÃO: A presença intracelular do H. pylori em leveduras orais sugere uma relação endossimbiótica desses microrganismos, o que poderia favorecer a transmissão e a reinfecção do H. pylori no trato gastrointestinal. 


\section{REFERENCES}

1. Palomino Camargo C, Tomé Boschian E. Helicobacter pylori: rol del agua y los alimentos en su transmisión. An Venez Nutr. 2012;25(2):85-93.

2. Matamala-Valdés L, Sánchez-Alonzo K, Parra C, Sáez K, Aguayo-Reyes A, García A. Detection of intracellular Helicobacter pylori in Candida spp from neonate oral swabs. Rev Assoc Med Bras. 2018;64(10):928-35.

3. Wroblewski LE, Peek RM Jr, Wilson KT. Helicobacter pylori and gastric cancer: factors that modulate disease risk. Clin Microbiol Rev. 2010;23(4):713-39.

4. Quaglia NC, Dambrosio A. Helicobacter pylori: a foodborne pathogen? World J Gastroenterol. 2018;24(31):3472-87.

5. Brown LM. Helicobacter pylori: epidemiology and routes of transmission. Epidemiol Rev. 2000;22(2):283-97.

6. Asokan GV, Ramadhan T, Ahmed E, Sanad H. WHO global priority pathogens list: a bibliometric analysis of Medline-PubMed for knowledge mobilization to infection prevention and control practices in Bahrain. Oman Med |. 2019;34(3):184-93.

7. Ferreccio C, Rollán A, Harris PR, Serrano C, Gederlini A, Margozzini P, et al. Gastric cancer is related to early Helicobacter pylori infection in a high-prevalence country. Cancer Epidemiol Biomarkers Prev. 2007;16(4):662-7.

8. World Health Organization. Global priority list of antibiotic-resistant bacteria to guide research, discovery, and development of new antibiotics. [cited 2018 lan 06]. Available from: http://www.who.int/medicines/publications/ global-priority-list-antibiotic-resistant-bacteria/en/

9. Lai $\mathrm{CH}$, Huang $\mid \mathrm{C}$, Cheng HH, Wu MC, Huang MZ, Hsu HY, et al. Helicobacter pylori cholesterol glucosylation modulates autophagy for increasing intracellular survival in macrophages. Cell Microbiol. 2018;20(12):e12947.

10. Siavoshi F, Saniee P. Vacuoles of Candida yeast as a specialized niche for Helicobacter pylori. World J Gastroenterol. 2014;20(18):5263-73.

11. Medina ML, Medina MG, Merino LA. Correlation between virulence markers of Helicobacter pylori in the oral cavity and gastric biopsies. Arq Gastroenterol. 2017;54(3):217-21.

12. Rutayisire E, Huang K, Liu Y, Tao F. The mode of delivery affects the diversity and colonization pattern of the gut microbiota during the first year of infants' life: a systematic review. BMC Gastroenterol. 2016;16(1):86.

13. Karczewska E, Wojtas I, Sito E, Trojanowska D, Budak A, Zwolinska-Wcislo $\mathrm{M}$, et al. Assessment of co-existence of Helicobacter pylori and Candida fungi in diseases of the upper gastrointestinal tract. J Physiol Pharmacol. 2009;60(Suppl 6):33-9.
14. Siavoshi F, Taghikhani A, Malekzadeh R, Sarrafnejad A, Kashanian M, Jama AS, et al. The role of mother's oral and vaginal yeasts in transmission of Helicobacter pylori to neonates. Arch Iran Med. 2013;16(5):288-94.

15. Pais P, Galocha M, Viana R, Cavalheiro M, Pereira D, Teixeira MC. Microevolution of the pathogenic yeasts Candida albicans and Candida glabrata during antifungal therapy and host infection. Microb Cell. 2019;6(3):142-59.

16. Chaieb K, Kouidhi B, Zmantar T, Mahdouani K, Bakhrouf A. Starvation survival of Candida albicans in various water microcosms. J Basic Microbiol. 2011;51(4):357-63.

17. Hooi JKY, Lai WY, Ng WK, Suen MMY, Underwood FE, Tanyingoh D, et al. Global prevalence of Helicobacter pylori infection: systematic review and meta-analysis. Gastroenterology. 2017;153(2):420-9.

18. Parra-Sepúlveda C, Merino JS, Sáez-Carrillo K, González C, García-Cancino A. Antibiotic resistance surveillance of Helicobacter pylori at the Biobío region (Chile) in a decade. Arq Gastroenterol. 2019;56(4):361-66.

19. Saniee P, Siavoshi F, Nikbakht Broujeni G, Khormali M, Sarrafnejad A, Malekzadeh R. Immunodetection of Helicobacter pylori-specific proteins in oral and gastric Candida yeasts. Arch Iran Med. 2013;16(11):624-30.

20. Hogan DA, Kolter R. Pseudomonas-Candida interactions: an ecological role for virulence factors. Science. 2002;296(5576):2229-32.

21. Bianciotto $V$, Genre A, Jargeat $P$, Lumini E, Bécard G, Bonfante P. Vertical transmission of endobacteria in the arbuscular mycorrhizal fungus Gigaspora margarita through generation of vegetative spores. Appl Environ Microbiol. 2004;70(6):3600-8

22. Webb BC, Thomas C), Willcox MD, Harty DW, Knox KW. Candida-associated denture stomatitis. Aetiology and management: a review. Part 1. Factors influencing distribution of Candida species in the oral cavity. Aust Dent J. 1998;43(1):45-50

23. Lynch DP. Oral candidiasis. History, classification, and clinical presentation. Oral Surg Oral Med Oral Pathol. 1994;78(2):189-93.

24. Wang XM, Yee KC, Hazeki-Taylor N, Li J, Fu HY, Huang ML, et al. Oral Helicobacter pylori, its relationship to successful eradication of gastric $\mathrm{H}$. pylori and saliva culture confirmation. J Physiol Pharmacol. 2014;65(4):559-66.

25. Al-Ahmad A, Kürschner A, Weckesser S, Wittmer A, Rauberger H, Jakob T, et al. Is Helicobacter pylori resident or transient in the human oral cavity? | Med Microbiol. 2012;61(Pt 8):1146-52. 